\title{
Chemometrics Analysis for the Groundwater Quality Assessment in UIN Walisongo Semarang
}

\author{
Kustomo $^{1, *}$ Rasidah $^{2}$, Daru Oktaviano ${ }^{1}$ \\ ${ }^{1}$ Department of Chemistry, Universitas Islam Negeri Walisongo, Semarang, Indonesia \\ ${ }^{2}$ Department of Chemistry, Universitas Palangka Raya, Central Kalimantan, Indonesia \\ ${ }^{*}$ Corresponding author. Email kustomo@walisongo.ac.id
}

\begin{abstract}
The purpose of this study was to analyze the quality of groundwater in terms of physical, chemical, and microbiological parameters at three campus locations of the Universitas Islam Negeri (UIN) Walisongo Semarang, Indonesia then the results were compared to the Regulation of the Ministry of Health of the Republic of Indonesia (Permenkes) Number 32 of 2017 regarding the water quality standards and environmental health. Principal Component Analysis (PCA) is one of chemometric modelling which can be used to analyze correlations among different physical, chemical and microbiological parameters to assess the groundwater quality at the water intake of dug wells as the main source of water in this study. The content of organic and inorganic materials are then associated with environmental factors, research activities and industrial pollution around campus. The implementation of PCA data in the water intake at dug wells offers new possibilities for improved quality assurance and control procedures for dug wells management and its strategy. Before Cluster Analysis (CA) and PCA methods are applied, the data was checked the normal distribution using the Saphiro-Wilk test. Furthermore, three different patterns of water quality based on groundwater characteristics and anthropogenic effects were found by CA and PCA methods.
\end{abstract}

Keywords: chemometrics, groundwater quality, UIN Walisongo.

\section{INTRODUCTION}

Groundwater is the most source of water for human activities in agricultural, industrial, office building, and domestic requirements [1]. The main problem faced related to the groundwater resources is the quantity of water that is insufficient with supply demand and the quality of water based on water quality standard of World Health Organization (WHO). [2]. The groundwater quality depends on natural factors like the interaction between groundwater and host aquifer materials, quality of infiltrating water, the residence time of the element, evaporite dissolution, etc [3]. Analysis of groundwater regarding physical, chemical, and microbiological parameters of water quality is important because it gives us information on conditions and contaminants inside water, compare it to the water quality standard (Indonesia Ministry of Health Decree $\mathrm{Nb}$. 32/2017) and treatment option to maintain of water pollution [4].

The rapid growth of population in Semarang city creates unprecedented challenges, among them is provision for clean water to the urban people [5].
Suhartono [6] predicted that Semarang city will experience a water crisis in 2030 because of the water demand for industries up to $90 \%$ of water taken from the ground at $3.17 \times 106 \mathrm{~m}^{3}$ per day, then the water demand for inhabitant amounted to $263,267 \mathrm{~m}^{3}$ per day. There are several water resources which are employed to supply water to the Semarang city: (a) Regional Water Supply Agency or in Indonesian language is Perusahaan Daerah Air Minum (PDAM) from Kaligarang and Kudu rivers (b) Underground water from dug wells and aquifer, and (c) Java seawater in the coastal area.

UIN Walisongo is one of public university under Ministry of Religious Affairs of Republic of Indonesia. It is located in the Ngaliyan Subdistrict, Semarang city, Central Java and it has three campus location (i.e. Campus 1, Campus 2, and campus 3) by using the groundwater as the main source of water for all activities inside campus. UIN Walisongo has a groundwater depth about 15-30 meters, with a level of soil permeability based on high lithology type is between 8,149 to 203,735 liters $/ \mathrm{m}^{2}$ /day [7]. In addition, 
UIN Walisongo Semarang also has a large number of employees both lecturers and administration services around 1,012 people [8] and the number of students around 17,640 [9]. Increasing of activities inside campus without good management could make a pollution to the groundwater. If the groundwater gets contaminated, it is very difficult and expensive to clean up and restore its quality [10].

Chemometrics is part of the chemical discipline which uses statistical and mathematical methods to solve problem based on scientific data. It can be used as one of methods in chemical analytics, biology, physics, medicine, pharmacy, forensic science, industry, and halal authentication [11]. Chemometrics are divided into two main categories, i.e. pattern recognition methods to qualitative analyses and multivariate calibration to quantitative analyses [12-13]. Chemometric tools like Cluster Analyses (CA) and Principal Component
Analysis (PCA) can be used to evaluate and analyze correlations of physical, chemical, and microbiological parameters of the groundwater quality among three different campus location at the UIN Walisongo Semarang as the aims of this research.

\section{METHODS}

\subsection{Groundwater Sampling}

To achieve the purpose of the study, the groundwater samples were collected from 3 campus location of UIN Walisongo Semarang. The position (latitude and longitude) of the sample points was using help notes for Google-based GPS (Table 1.). Groundwater was drawn from dug wells after 10 minutes of pre-washing to obtain fresh water and to remove stagnant water in previously cleaned polyethylene bottles with a capacity of 5 liter.

Table 1. Global Positioning System (GPS) Coordinates of Sampling Sites

\begin{tabular}{|l|l|l|l|}
\hline Sampling Site & Longitude & Latitude & Elevation above the Sea level $(\mathrm{m})$ \\
\hline Campus 1 & 110.35884 & -6.98676 & 2.15 \\
\hline Campus 2 & 110.35216 & -6.99001 & 6.41 \\
\hline Campus 3 & 110.34666 & -6.99179 & 10.27 \\
\hline
\end{tabular}

Figure 1 show that after each sample was taken, the bottle was clearly labelled with waterproof ink and the details of each.



Figure 1 Labelling of the Groundwater Samples

\subsection{Analytical Methods}

The water samples were collected in 5 Liter bottles cleaned, rinsed and sterilized for physical and chemical analysis, in addition dark and sterilized $250 \mathrm{~mL}$ bottles were used for microbiological analysis. For heavy metal analysis, water samples were taken in separate 5 Liter bottles and preserved by the addition of ultra-pure nitric acid. These samples were brought to the laboratory keeping the temperature below $4^{\circ} \mathrm{C}$. The microbiological analysis was completed within 24 hours after sampling. Physical and chemical parameters such as $\mathrm{pH}$, temperature, color, taste, odor and turbidity were analyzed in situ. The other parameters such as Total Dissolved Solids (TDS), nitrite $\left(\mathrm{NO}_{2}\right)$, nitrate $\left(\mathrm{NO}_{3}\right)$, arsenic (As), iron $(\mathrm{Fe})$, fluoride $(\mathrm{F})$, chromium $(\mathrm{Cr})$, manganese $(\mathrm{Mn})$, zinc $(\mathrm{Zn})$, cyanide $(\mathrm{CN})$, sulfate $\left(\mathrm{SO}_{4}\right)$, hardness $\left(\mathrm{CaCO}_{3}\right)$, trace organic pollutants $\left(\mathrm{KMnO}_{4}\right)$ and microbiological parameters such as Total Coliforms and E-Coli were analyzed in the laboratory.

TDS, $\mathrm{pH}$ and temperature were measured with a water quality tester (EZ-9901) and turbidity with a nephelometer (SGZ-200BS). Colorimetric analyzes such as sulfate, fluoride, nitrite, and nitrate were measured with a UV-Vis spectrophotometer (DR-5000, Hach, USA). Heavy metal ions were analyzed with an Atomic Absorption Spectrophotometer (Thermo Fisher Scientific iCE-3500) and for microbiological analysis they were measured by the Most Probable Number (MPN) method. MPN is a statistical method to estimate the viable number of bacteria in a sample by inoculating broth at a 10-fold dilution and is based on the extinction dilution principle. It is widely used to estimate bacterial cells in food and water [14-15]. The Saphiro Wilk test was utilized to decide the information of distribution data, uncovering that the information was not regularly conveyed [16]. Multivariate statistical analysis was performed using SPSS Version 22 to perform Principal Component Analysis (PCA) and Cluster Analysis (CA). 
PCA is planned to change over the initial factors into new, uncorrelated factors, called the Principal Components (PCs). The value of eigenvalues and eigenvectors were gotten from the Pearson correlation lattice of key factors by utilizing PCA. The eigenvalues of the PCs are a degree of their comparing fluctuations. $\mathrm{CA}$ is considered as an unsupervised pattern recognition procedure, was utilized to classify our dataset. The reason of utilizing $\mathrm{CA}$ was to distinguish similitudes and dissimilarities among the sampling sites.

\section{RESULT AND DISCUSSION}

\subsection{Environmental Factors and Physical Parameters}

Tools to be used to take the groundwater samples must be appropriately sterilized, cleaned and decontaminated. The chemical elements of interest in subsequent laboratory analysis dictate the type of container to be used for sampling and for sample storage, e.g. plastic or borosilicate glass [17]. Three sites of sampling used simple random sampling among three location of Campus (Fig. 2). To guarantee the unwavering and interpretability of the collect information, suitable documentation ought to be joined into the observing program that records test development from collection to information announcing and guarantees that explanatory information is credited to the proper areas.

Among three sampling sites of UIN Walisongo Campus (Figure 2.), it has different type of structural land and environmental factors. Campus 1 has a horizontal land structure and is surrounded by industrial estates and densely populated settlements. Then, campus 2 and 3 has a hilly soil structure and is surrounded by mini forest in the Western part of it. The surface water temperature, $\mathrm{pH}$, turbidity, and TDS were in the ranges of 28.6-30.3 ${ }^{\circ} \mathrm{C}, 6.83-7.63,0.38-0.75$ NTU, and 148.5-662 mg/L, respectively (Table 2). TDS in Campus 1 of UIN Walisongo Semarang has a higher concentration than the others because of the condition of this place surrounded some industrial estate so it makes an effect for the quality of water. Based on the Indonesia Ministry of Health Decree Number 32 Year of 2017, the amount of TDS should be less than 1000 $\mathrm{mg} / \mathrm{L}$ if the water used for clean water, hygiene sanitation, bathhouse, and swimming pool, but if it is used for drinking water should be less than $500 \mathrm{mg} / \mathrm{L}$ (Indonesia Ministry of Health Decree Number 492/2010) [18].

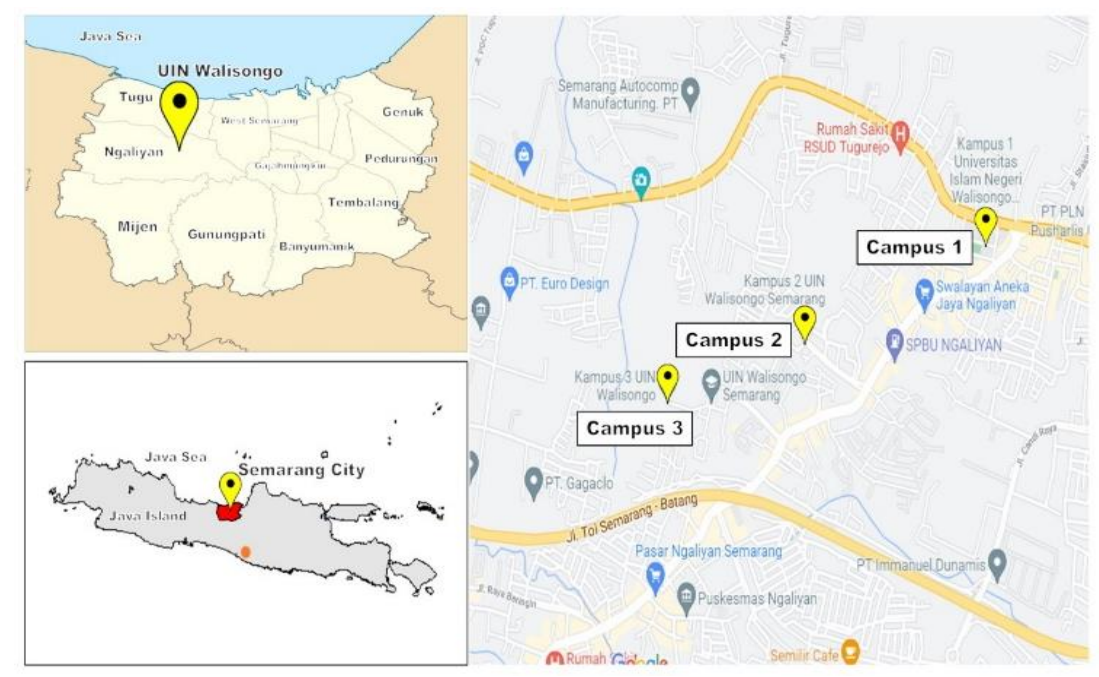

Figure 2 Groundwater Sampling Site

Table 2. Physical parameters assessments

\begin{tabular}{cccccccc}
\hline & \multicolumn{7}{c}{ Physical } \\
Sites & Parameters & $\mathbf{p H}$ & Turbidity (NTU) & Temperature $\left({ }^{\circ} \mathbf{C}\right)$ & Color Taste Odor & TDS \\
\cline { 2 - 9 } & 6.83 & 0.38 & 28.6 & 0 & 0 & 0 & 662.0 \\
Campus 1 & 7.41 & 0.69 & 30.1 & 0 & 0 & 0 & 174.4 \\
Campus 2 & 7.63 & 0.75 & 30.3 & 0 & 0 & 0 & 148.5 \\
Campus 3 & $6.5-8.5$ & 25 & Room Temperature $\pm 3^{\circ} \mathrm{C}$ & 0 & 0 & 0 & $<1000$ \\
Water Quality Standard & & &
\end{tabular}




\subsection{Chemical Parameters}

The chemical parameters of heavy metals (As, Fe, F, $\mathrm{Cr}, \mathrm{Mn}, \mathrm{Zn})$, Cyanide $(\mathrm{CN})$, hardness $\left(\mathrm{CaCO}_{3}\right)$, and trace organic pollutants $\left(\mathrm{KMnO}_{4}\right)$ in the groundwater are important to determine the feasibility of water as a source of activities around the UIN Walisongo Campus. Heavy metals are non-degradable compounds or cannot be decomposed and have a higher density than water, so that heavy metals from industrial waste and laboratory activities around campus are infiltrated and contaminated to the groundwater [19]. Table 3. shows that all tested groundwater samples contained heavy metals and organic substances below the tolerance limit of the water quality standard for in accordance with the Regulation of the Ministry of Health of the Republic of Indonesia Number 32 of 2017.

Table 3. Chemical parameters assessment

\begin{tabular}{|c|c|c|c|c|c|c|c|c|c|c|c|c|}
\hline \multirow[b]{2}{*}{ Sites } & \multicolumn{12}{|c|}{ Chemical (mg/L) } \\
\hline & Arsen (As) & $\operatorname{Iron}(\mathrm{Fe})$ & Fluorida (F) & $\mathrm{CaCO}_{3}$ & $\mathrm{Cr}(\mathrm{VI})$ & Mn & $\mathrm{NO}_{3}$ & $\mathrm{NO}_{2}$ & $\mathbf{Z n}$ & $\mathbf{C N}$ & $\mathrm{SO}_{4}$ & $\mathrm{KMnO}_{4}$ \\
\hline Campus 1 & 0.005 & 0.030 & 0.10 & 678.80 & 0.05 & 0.10 & 1 & 0.01 & 0.43 & 0.036 & 2 & 3.60 \\
\hline Campus 2 & 0.005 & 0.020 & 0.57 & 199.20 & 0.03 & 0.00 & 0.90 & 0.01 & 0.09 & 0.003 & 1 & 2.43 \\
\hline Campus 3 & 0.005 & 0.003 & 0.10 & 184.00 & 0.00 & 0.00 & 0.60 & 0.01 & 0.25 & 0.001 & 0 & 3.63 \\
\hline $\begin{array}{l}\text { Maximum Concentration of } \\
\text { the Water Quality Standard }\end{array}$ & 0.05 & 1 & 1.5 & 500 & 0.05 & 0.5 & 10 & 1 & 15 & 0.1 & 400 & 10 \\
\hline
\end{tabular}

Besides, the concentration of hard water on campus 1 exceeds the tolerance limit of the water quality standards based on the Regulation of the Ministry of Health of the Republic of Indonesia Number 32 of 2017. It might be happening because the site of Campus 1 is close to the coastal area of Java sea which has a geomorphological of rock in the form of solid limestone from coastal area with a hollow rock arrangement, thus allowing groundwater to flow through the aquifers. The content of limestone could make change in physicochemical of groundwater due to the mass transfer reaction of the dissolution of minerals limestone [20], such as calcite $\left(\mathrm{CaCO}_{3}\right)$, dolomite $\left(\mathrm{CaMg}\left(\mathrm{CO}_{3}\right)_{2}\right)$, gypsum $\left(\mathrm{CaSO}_{4} \cdot 2 \mathrm{H}_{2} \mathrm{O}\right)$, and amorphous silica [20]. The degree of hardness in different waters varies, groundwater has a high hardness, it happens because the groundwater is in contact with limestone in the soil layer through which the water flows. Surface water has low hardness (soft water), non-carbonate hardness in surface water comes from calcium sulfate, found in clay and other sediments [21]. The classification of the degree of hardness in the groundwater is showed in Table 4

Table 4. The degree of hardness $\left(\mathrm{CaCO}_{3}\right)$ in the water [21]

\begin{tabular}{|l|l|}
\hline $\begin{array}{l}\text { Content of hardness } \\
\left(\mathrm{CaCO}_{3}\right), \mathrm{mg} / \mathrm{L}\end{array}$ & Degree of hardness \\
\hline $0-75$ & Soft \\
\hline $75-150$ & Moderate \\
\hline $150-300$ & Hard \\
\hline$>300$ & Very hard \\
\hline
\end{tabular}

\subsection{Microbiological Parameters}

Other mandatory of the groundwater quality requirements, namely microbiology or bacteriologist parameters. It states the presence of Escherichia Coli (EColi) and Total Coliform bacteria in water in the Colony Forming Unit (CFU) of quantity per $100 \mathrm{~mL}$ of sample. The maximum allowable level is zero $(0)$ for E-Coli bacteria and $50 \mathrm{CFU} / 100 \mathrm{~mL}$ for Total Coliform bacteria. E-Coli bacteria can cause epidemics of digestive tract diseases such as cholera, typhus, dysentery, diarrhea and helminthiasis. The seeds of this disease come from the feces of humans who suffer from these diseases. An indicator that shows that ground water is contaminated with feces is the presence of Escherichia coli in the water because human feces, both sick and healthy, contain these bacteria in the body [22]. Table 5. show the amounts of E-Coli and Total Coliform bacteria presence in the ground water at the third Campus of UIN Walisongo is zero, so it meets the requirements and viable to use according to the Regulation of the Indonesia Ministry of Health $\mathrm{Nb}$. 32/2017.

Table 5. Microbiological parameter assessments

\begin{tabular}{ccc}
\hline & Parameters & \multicolumn{2}{c}{ Microbiology $($ CFU/100 mL $)$} \\
\cline { 2 - 3 } Sites & E-Coli & Total Coliform \\
\hline Campus 1 & 0 & 0 \\
Campus 2 & 0 & 0 \\
Campus 3 & 0 & 0 \\
Water Quality Standard & 0 & 50 \\
\hline
\end{tabular}




\subsection{Chemometric Analysis}

To assess spatial variations in water contaminant concentrations in samples taken from three sampling sites in UIN Walisongo Semarang, a chemometric approach was used using the following exploratory techniques: the Shapiro-Wilk Test, CA and PCA. Before analysis, the data were converted into a single matrix composed of concentration values for each combination of variables (16 physicochemical parameters) and cases
(48 samples). Since color, odor, taste, E-Coli, and Total coliforms were never detectable and showed no variation, they were excluded from the analysis and the resulting data matrix was thus reduced to a [16 $\times 48]$ data matrix. Data that were below the method's detection limit $(<\mathrm{MDL})$ were supplemented with values corresponding to half the detection limit of [23]. The normal distribution tests were performed using the Shapiro-Wilk test (Table 6).

Table 6. the Normal distribution test using the Shapiro-Wilk

\begin{tabular}{|c|c|c|c|c|c|c|c|}
\hline & \multirow[b]{2}{*}{ Parameters } & \multicolumn{3}{|c|}{ Kolmogorov-Smirnov ${ }^{a}$} & \multicolumn{3}{|c|}{ Shapiro-Wilk } \\
\hline & & Statistic & df & Sig. & Statistic & df & Sig. \\
\hline \multirow[t]{14}{*}{ Physicochemical } & Temperature & .346 & 3 & . & .837 & 3 & .206 \\
\hline & Turbidity & .329 & 3 & & .868 & 3 & .290 \\
\hline & TDS & .369 & 3 & & .788 & 3 & .086 \\
\hline & $\mathrm{pH}$ & .281 & 3 & & .937 & 3 & .515 \\
\hline & $\mathrm{Fe}$ & .235 & 3 & & .978 & 3 & .716 \\
\hline & $\mathrm{F}$ & .385 & 3 & & .750 & 3 & .000 \\
\hline & $\mathrm{CaCO} 3$ & .376 & 3 & & .773 & 3 & .052 \\
\hline & $\mathrm{Cr}$ & .219 & 3 & & .987 & 3 & .780 \\
\hline & $\mathrm{Mn}$ & .385 & 3 & & .750 & 3 & .000 \\
\hline & NO3 & .292 & 3 & & .923 & 3 & .463 \\
\hline & $\mathrm{Zn}$ & .182 & 3 & & .999 & 3 & .935 \\
\hline & $\mathrm{CN}$ & .367 & 3 & & .793 & 3 & .097 \\
\hline & $\mathrm{SO} 4$ & .175 & 3 & & 1.000 & 3 & 1.000 \\
\hline & $\mathrm{KMnO} 4$ & .377 & 3 & & .769 & 3 & .042 \\
\hline
\end{tabular}

The concordance of the distribution of the pollutant concentrations of the groundwater with the normal distribution was verified by omitting the parameters of As and $\mathrm{NO}_{2}$. Besides that, the chemical parameters of $\mathrm{Mn}$ and $\mathrm{SO}_{4}$ also has been omitted to the next CA analysis because of the Sig. value $<0.05$. Table 6. show that the descriptive statistics of the physicochemical parameters at three sampling sites of UIN Walisongo Semarang. Initially, CA (also known as unsupervised pattern recognition) was used to discover natural clusters in real data, both in terms of similarity of sampling sites and physicochemical parameters within the study regions.

Table 7. Descriptive statistics of the physicochemical parameters

Descriptive Statistics

\begin{tabular}{|l|r|r|r|r|r|}
\hline & $\mathrm{N}$ & Minimum & Maximum & \multicolumn{1}{c|}{ Mean } & Std. Deviation \\
\hline $\mathrm{pH}$ & 3 & 6.83 & 7.63 & 7.2900 & .41328 \\
Turb & 3 & .38 & .75 & .6067 & .19858 \\
Temp & 3 & 28.60 & 30.30 & 29.6667 & .92916 \\
$\mathrm{TDS}$ & 3 & 148.50 & 662.00 & 328.3000 & 289.28268 \\
$\mathrm{Fe}$ & 3 & .00 & .03 & .0177 & .01365 \\
$\mathrm{CaCO} 3$ & 3 & 184.00 & 678.80 & 354.0000 & 281.38770 \\
$\mathrm{Cr}$ & 3 & .00 & .05 & .0267 & .02517 \\
$\mathrm{NO} 3$ & 3 & .60 & 1.00 & .8333 & .20817 \\
$\mathrm{Zn}$ & 3 & .09 & .43 & .2567 & .17010 \\
$\mathrm{CN}$ & 3 & .00 & .04 & .0133 & .01966 \\
$\mathrm{SO} 4$ & .00 & 2.00 & 1.0000 & 1.00000 \\
$\mathrm{KMnO} 4$ & 3 & 3.63 & 3.2200 & .68432 \\
Valid N (listwise) & 3 & 2.43 & 3.63 & \\
\hline
\end{tabular}


$\mathrm{CA}$ is a common method to classify variables or cases (observations / samples) into clusters with high similarity within the class and high dissimilarity between different classes with respect to a given selection criterion (Fig. 3). The CA results help to interpret the data and reveal patterns using hierarchical cluster. The hierarchical method is a grouping technique that forms a hierarchical construction or based on certain levels such as tree structures, so that the grouping process is carried out in stages or stages [24].

Before conducting the PCA, the Bartlett's sphericity tests were performed on the parameter correlation matrix to examine the validity of the PCA. PCA was applied to data sets converted to standard logs (12 parameters) to examine differences among three sampling sites and identify latent factors. Based on the Scree plot (Fig. 4) for PCA and eigenvalue criteria, only PCs with eigenvalues $>1$ were considered essential. PCA from the two data sets yielded four PCs for component 1 and 2, accounting for $81.572 \%$ and $18.428 \%$ of the total variance in the water quality data sets respectively. Table 8 summarizes the PCA results including component, Eigenvalues, and Extraction Sums of Squared load whose absolute value is greater than compared to 0.7 of the total variances.

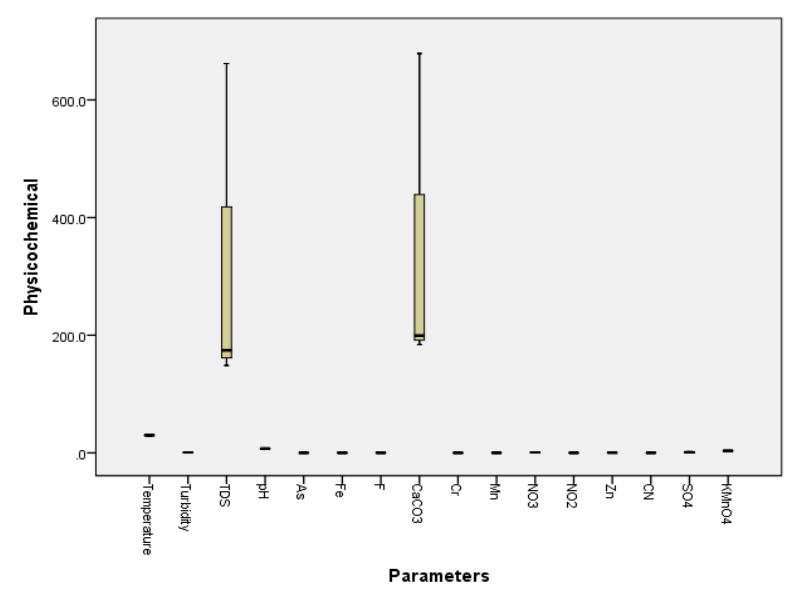

Figure 3 Dendogram of CA analysis using the single linkage (Nearest neighbor method) of physicochemical parameters

Table 8. PCA's method for 12 physicochemical parameters of the groundwater quality

Total Variance Explained

\begin{tabular}{|l|r|r|r|r|r|r|}
\hline \multirow{2}{*}{ Component } & \multicolumn{3}{|c|}{ Initial Eigenvalues } & \multicolumn{2}{c|}{ Extraction Sums of Squared Loadings } \\
\cline { 2 - 7 } & \multicolumn{1}{|c|}{ Total } & \% of Variance & Cumulative \% & Total & \% of Variance & Cumulative \% \\
\hline 1 & 9.789 & 81.572 & 81.572 & 9.789 & 81.572 & 81.572 \\
3 & 2.211 & 18.428 & 100.000 & 2.211 & 18.428 & 100.000 \\
4 & $8.313 \mathrm{E}-16$ & $6.928 \mathrm{E}-15$ & 100.000 & & & \\
5 & $5.025 \mathrm{E}-16$ & $4.188 \mathrm{E}-15$ & 100.000 & & & \\
6 & $3.786 \mathrm{E}-16$ & $3.155 \mathrm{E}-15$ & 100.000 & & & \\
7 & $2.220 \mathrm{E}-16$ & $1.850 \mathrm{E}-15$ & 100.000 & & & \\
8 & $2.182 \mathrm{E}-16$ & $1.818 \mathrm{E}-15$ & 100.000 & & & \\
9 & $-7.573 \mathrm{E}-17$ & $-6.311 \mathrm{E}-16$ & 100.000 & & & \\
10 & $-2.578 \mathrm{E}-16$ & $-2.148 \mathrm{E}-15$ & 100.000 & & & \\
11 & $-4.198 \mathrm{E}-16$ & $-3.499 \mathrm{E}-15$ & 100.000 & & & \\
12 & $-1.108 \mathrm{E}-15$ & $-9.236 \mathrm{E}-15$ & 100.000 & & & \\
\hline
\end{tabular}

Extraction Method: Principal Component Analysis.

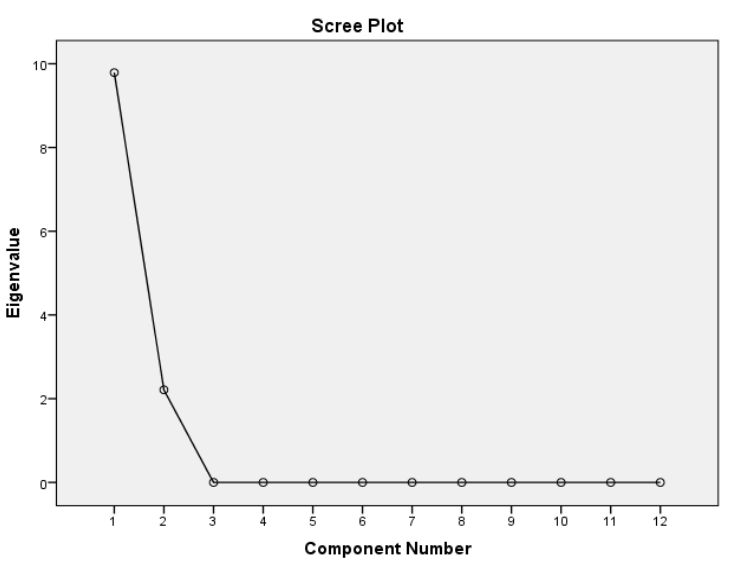

Figure 4. Scree plot of PCA's method

\section{CONCLUSION}

Chemometric analysis was applied to the groundwater quality assessments and monitoring in UIN Walisongo to find relationships among the variables. CA helped uncover similarities between the groundwater and pollutants. Three groups were formed for each case. CA's ability to show similarities between pollutants is interesting because polluted water is a new environmental problem and therefore there are currently insufficient data on environmental behavior and the fate of most groundwater quality in UIN Walisongo. PCA has been implemented as an exploratory technique for data recognition, this phenomenon highlights the fact 
that physicochemical parameters help groundwater restore water quality. Using PCA as a classification model, it is not only possible to highlight pollution sources and assign resource recovery itself, but also to highlight events, such as satisfactory wastewater treatment and diffuse organic pollution, represented by incorrectly classified samples.

\section{ACKNOWLEDGMENT}

We gratefully acknowledge to the Ministry of Religious Affairs of Republic of Indonesia and BOPTN DIKTIS 2021 via the LPPM UIN Walisongo Semarang for supporting this project. We also would like to thank to the Integrated Laboratory of the Faculty of Science and Technology UIN Walisongo Semarang and Health Laboratory of Semarang as a place for scientific analysis of the groundwater quality.

\section{REFERENCES}

[1] N. Khan, A. Malik, K. Nehra, Groundwater hydrogeochemistry, quality, microbiology and human health risk assessment in semi-arid area of Rajasthan, India: a chemometric approach, in: Enviromental Monitoring and Assessment, vol. 193(4), Springer, Berlin, Heidelberg, 2021. DOI: 10.1007/s10661-021-08979-2

[2] E.B. Sasongko, E. Widyastuti, R.E. Priyono, Study of water quality and utility of dug well to the people around Kaliyasa Rivers, Cilacap, in: Jurnal Ilmu Lingkungan, vol. 12(2), 2014, pp. 72. DOI: 10.14710/jil.12.2.72-82

[3] N. Malik, A. Malik, S. Bishnoi, Assessment of groundwater hydro-geochemistry, quality, and human health risk in arid area of India using chemometric approach, in: Arabian Journal of Geosciences., vol. 14(15), 2021. DOI: 10.1007/s12517-021-07852-3.

[4] Ministry of Health of Republic of Indonesia, Indonesia Ministry of Health Decree Number 32 Year 2017 concerning in water quality standard for hygiene sanitation, swimming pool, solute per aqua and public bath, Jakarta, 2017.

[5] BPS Semarang, The population and housing in Semarang City, Semarang, 2019.

[6] E. Suhartono, P. Purwanto, S. Suripin, Seawater intrusion modeling on groundwater confined aquifer in Semarang, in: Procedia Environmental Sciences, vol. 23, 2015, pp. 110-115. DOI: 10.1016/j.proenv.2015.01.017

[7] F. Alihar, Penduduk dan akses air bersih di Kota Semarang (Population and access to clean water in
Semarang City), in: Jurnal Kependudukan Indonesia, vol. 13, 2018, pp. 67-76.

[8] Sistem Informasi Pegawai UIN Walisongo, 2021. http://simpeg.walisongo.ac.id/ (accessed June 06, 2021)

[9] Education and Culture Ministry of Republic of Indonesia, PDDikti -The information system and data of Indonesia higher education, 2021. https://pddikti.kemdikbud.go.id/data_pt/MDk3OT UyODItNzRERC00OTJCLTgwMjMtRjVERTk1N zdFRTY3 (accessed October 15, 2021).

[10] H. Gao, et al., Chemometrics data of water quality and environmental heterogeneity analysis in $\mathrm{Pu}$ River, China, in: Environmental Earth Sciences, vol. 73(9), 2015, pp. 5119-5129. DOI: $10.1007 / \mathrm{s} 12665-015-4233-\mathrm{x}$

[11] M.H. Yuswan, et al., Chemometrics-assisted shotgun proteomics for establishment of potential peptide markers of non-halal pork (Sus scrofa) among halal beef and chicken, in: Food Analytical Methods, vol. 11(12), 2018, pp. 3505-3515. DOI: $10.1007 / \mathrm{s} 12161-018-1327-6$

[12] F. Zhou, H. Guo, Y. Liu, Y. Jiang, Chemometrics data analysis of marine water quality and source identification in Southern Hong Kong, in: Marine Pollution Bulletin, vol. 54(6), 2007, pp. 745-756. DOI: 10.1016/j.marpolbul.2007.01.006

[13] R. Muzyka, M. Chrubasik, M. Pogoda, M. Sajdak, Chemometric analysis of air pollutants in raw and thermally treated coals - low-emission fuel for domestic applications, with a reduced negative impact on air quality, in: Journal of Environmental Management, vol. 281, 2021, pp. 111787, 2021. DOI 10.1016/j.jenvman.2020.111787

[14] R. Petrisek, J. Hall, Evaluation of a most probable number method for the enumeration of Legionella pneumophila from North American potable and nonpotable water samples, in: Journal of Water and Health, vol. 16(1), 2018, pp. 57-69. DOI: 10.2166/wh.2017.118

[15] N. Fadhillah, M. Ma, H. Faizah, L. Chilmi, Kajian kelayakan kualitas sumber air tanah di UIN Sunan Ampel Surabaya dalam rangka menuju Eco Campus, in: Al-Ard: Journal Teknik Lingkungan, vol. 5(1), 2019, pp. 9-16. DOI: https://doi.org/10.29080/alard.v5i1.475

[16] A. Manbohi, S. Gholamipour, Utilizing chemometrics and geographical information systems to evaluate spatial and temporal variations of coastal water quality, in: Regional Studies in 
Marine Science, vol. 34, 2020, pp. 101077. DOI: 10.1016/j.rsma.2020.101077

[17] Department of Primary Industry and Resources, Methodology for the sampling of surface water, 2016, pp. 1-13. [Online]. Available: https://nt.gov.au/_data/assets/pdf_file/0014/20336 0/aa7-024-methodology-for-the-sampling-ofgroundwater-advisory-note.pdf.

[18] Ministry of Health of Republic of Indonesia, The Indonesia Ministry of Health Number 492/2010 regarding water quality standard for drinking, Jakarta, 2010.

[19] Y. Rohmawati, K. Kustomo, Analisis kualitas air pada reservoir PDAM Kota Semarang menggunakan uji parameter fisika, kimia, dan mikrobiologi, serta dikombinasikan dengan analisis kemometri, in: Walisongo Journal of Chemistry, vol. 3(2), 2020, pp. 100 . DOI: 10.21580/wjc.v3i2.6603.

[20] T. Spencer, Limestone coastal morphology: the biological contribution. In: Progress in Physical Geography: Earth and Environment, vol. 12(1), 1988, pp. 66-101. DOI: 10.1177/030913338801200103.
[21] M.K. Ahn, R. Chilakala, C. Han, T. Thenepalli, Removal of hardness from water samples by a carbonation process with a closed pressure reactor, in: Water, vol. 10(1), 2018, pp. 1-10. DOI: https://doi.org/10.3390/w10010054

[22] R. Seth, et al., Application of chemometric techniques in the assessment of groundwater quality of Udham Singh Nagar, Uttarakhand, India, in: Water Quality Exposure and Health, vol. 6(4), 2014, pp. 199-216. DOI: https://doi.org/10.1007/s12403-014-0127-5

[23] N.A. Al-Odaini, M.P. Zakaria, M.A. Zali, H. Juahir, M.I. Yaziz, S. Surif, Application of chemometrics in understanding the spatial distribution of human pharmaceuticals in surface water," in: Environmental Monitoring and Assessment, vol. 184(11), 2012, pp. 6735-6748. DOI: $10.1007 / \mathrm{s} 10661-011-2454-3$

[24] M.M. Pojić, N.B. Spasojević, M.D. Atlas, Chemometric approach to characterization of flour mill streams: chemical and rheological properties, in: Food and Bioprocess Technology, vol. 7(5), 2014, pp. 1298-1309. DOI: $10.1007 / \mathrm{s} 11947-013-$ $1133-5$. 